\title{
Study on Road Construction Technology of Low-lying and Swamp Area by Using Special Fine Sand
}

\author{
Zheng Wu, Fei Yang, Ke Lee
}

Powerchina Chengdu Engineering Corporation Limited, CEC, Chengdu, 610072, China

\begin{abstract}
According to the site condition of one of the oversea project located in the low-lying and swamp area, special fine sand with fine modulus in values of 0.42-0.62 was used to construct roads in the area through special workmanship and construction techniques. Bamboo materials are designed as piles and supporting system in a reasonable arrangement. The paper provides calculation details of the supporting system of bamboo materials, outlines the construction procedures and construction technique, and describes the contents of quality control and safety construction. It provides good references for road construction in low-lying and swamp areas in similar countries.
\end{abstract}

Key words: low-lying and swamp area; special find sand; bamboo material as piling and supporting system; road construction

\section{Introduction}

In some countries, such as Bangladesh, there is a lack of construction material even the aggregates for concrete work and road pavement work are imported from other countries. The local normal practices is to use burnt bricks, crush them to the required size and grade them as base and sub-base material in road work. Besides, there is also a shortage of good quality of sub-grade and road fill material.

One modern Sewage Treatment Plant (STP) project at Dasherkandi in Dhaka Bangladesh is under construction, the total length of the access road to the STP is $790 \mathrm{~m}$, of which there is $450 \mathrm{~m}$ section in the low-lying and swamp area, and the average water depth is $1.5-1.7 \mathrm{~m}$ in dry season and $2.5 \mathrm{~m}$ in wet season. The access road to STP has to cross the swamp area. The only available material for access road construction is the river sand, which is $40 \mathrm{~km}$ away from the project site. And the fine modulus of the river sand is $0.42-062$, which belongs to the special fine sand. The said sand is transported by the boat through the river near the project site and bump to the construction site by the activity of sand filling.

This article studied how to use special fine sand and environmentally friendly bamboo materials available on the local market to construct the access road. The result is summarized below.

\section{Road Design}

According to the contract, the top width of the access road is $7 \mathrm{~m}$, including $0.5 \mathrm{~m}$ wide shoulders in both sides. The access road to be used is temporary hauling road to transport construction material, machines and equipment for STP 
construction. After the construction of the STP, the access road will be upgrade to the permanent road.

\subsection{Cross section design}

The road cross section with bamboo pile design is shown in Figure 1. The bamboo inside the ground is about $2.5 \mathrm{~m}$. The bamboo pile is used to carry load from bamboo crossbeam, and the bamboo crossbeam is used to carry load from the bamboo stick, which is used to carry sand fill lateral load from the construction, the reinforcement is used to carry the horizontal load from the bamboo pile, and the section of bamboo pile under the ground is used to limit sliding and heaving of the road slope.

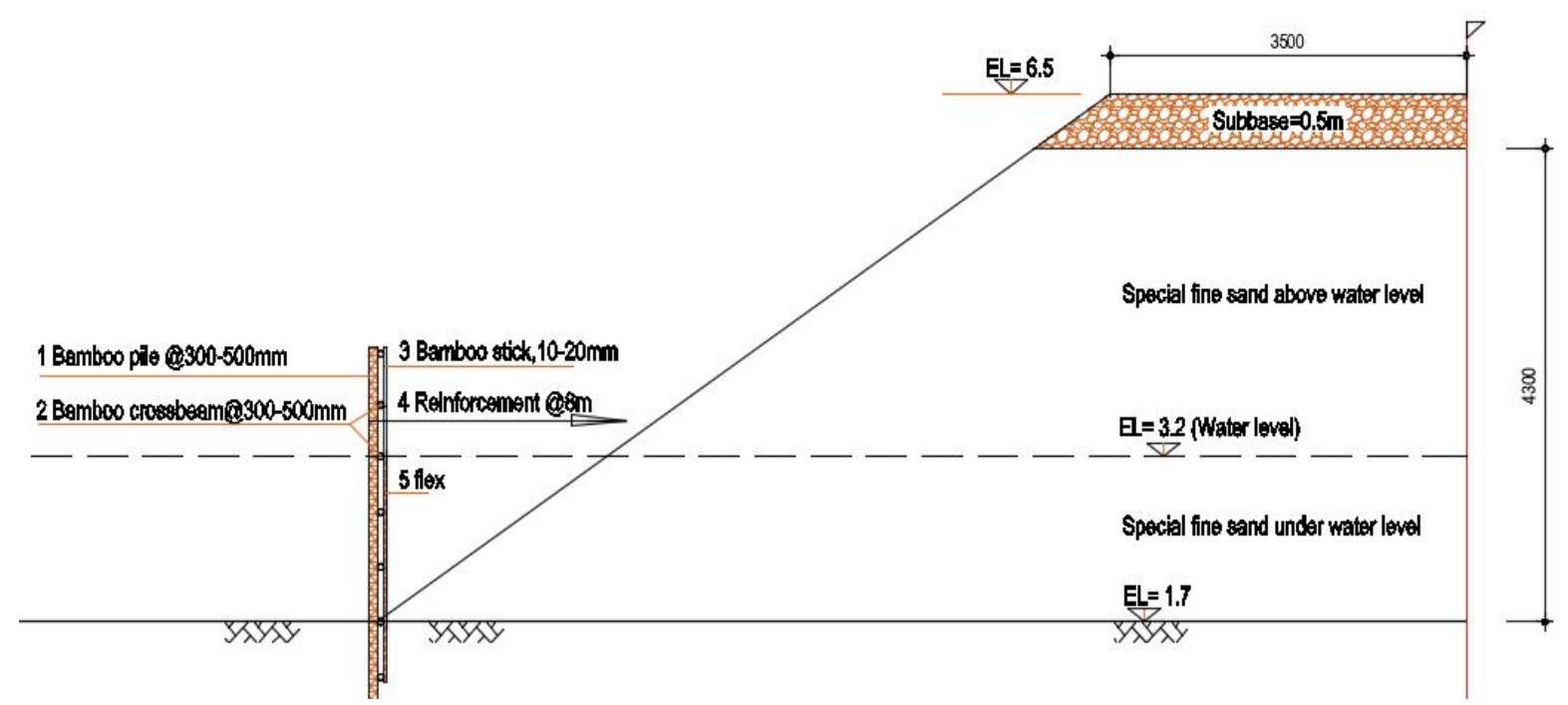

Figure 1. Road cross section design

\subsection{Geotechnical parameter of existing ground}

Geotechnical parameters of sub-base, fine sand and existing ground are listed in Table 1.

Table 1. Geotechnical parameter for sub-base, fine sand and existing ground

\begin{tabular}{|c|c|c|c|c|c|c|c|c|c|c|c|}
\hline \multirow{2}{*}{$\begin{array}{l}\text { Type of } \\
\text { soil }\end{array}$} & \multicolumn{2}{|c|}{ Soil depth (m) } & \multicolumn{2}{|c|}{$\begin{array}{l}\text { Density } \\
\left(\mathrm{kN} / \mathrm{m}^{3}\right)\end{array}$} & \multirow{2}{*}{$\begin{array}{c}\text { Internal } \\
\text { friction } \\
\text { angle } \\
\left(^{\circ}\right)\end{array}$} & \multirow{2}{*}{$\begin{array}{l}\text { Cohesive } \\
\text { (kPa) }\end{array}$} & \multirow{2}{*}{$\begin{array}{c}\text { Deformation } \\
\text { modulus } \\
\text { (MPa) }\end{array}$} & \multicolumn{2}{|c|}{ permeability (m/day) } & \multirow{2}{*}{$\begin{array}{l}\text { PI } \\
(\%)\end{array}$} & \multirow{2}{*}{ Remarks } \\
\hline & Depth & Thickness & Wet & Dry & & & & $\begin{array}{c}\text { Horizontal } \\
, \mathrm{Kh}\end{array}$ & $\begin{array}{c}\text { Vertical, } \\
\text { Kv }\end{array}$ & & \\
\hline $\begin{array}{c}\text { Sub-bas } \\
\text { e }\end{array}$ & & 0.5 & 16.80 & 15.6 & 35 & 0 & 37.50 & 20 & 20 & & $\begin{array}{l}\text { New } \\
\text { layer }\end{array}$ \\
\hline $\begin{array}{l}\text { Special } \\
\text { fine } \\
\text { sand }\end{array}$ & & 4.8 & 14.30 & 13.2 & 23.2 & 5.9 & 8.20 & 2.29 & 1.27 & & $\begin{array}{c}\text { Subgrade } \\
\text {, new } \\
\text { layer }\end{array}$ \\
\hline S1 & 9.5 & 9.5 & 19.5 & 18.2 & 29.7 & 0.6 & 6.72 & $3.22 \mathrm{E}-05$ & $2.47 \mathrm{E}-05$ & 28.1 & $\begin{array}{c}\text { Existing } \\
\text { ground }\end{array}$ \\
\hline $\mathrm{S} 2$ & 23.3 & 13.8 & 19.7 & 18.5 & 26.8 & 0.6 & 6.81 & $1.88 \mathrm{E}-05$ & $1.72 \mathrm{E}-05$ & 28.1 & $\begin{array}{c}\text { Existing } \\
\text { ground }\end{array}$ \\
\hline S3 & 27.1 & 3.8 & 19.5 & 18.5 & 29.2 & 1.00 & 6.55 & $2.66 \mathrm{E}-04$ & $2.45 \mathrm{E}-05$ & 28.6 & $\begin{array}{l}\text { Existing } \\
\text { ground }\end{array}$ \\
\hline
\end{tabular}

\section{Bamboo Material Parameter}

The local bamboo is light with good flexibility and high toughness. The tensile and compressive strength of bamboo along grain direction are $170 \mathrm{MPa}$ and $80 \mathrm{MPa}$ respectively. The local bamboo grows fast and yields high. Bamboo is green 
and environmentally friendly, it is widely used in construction materials, especially in local building market as formwork and false work material.

\subsection{Dimensions of bamboo structure}

As shown in Figure 1, the water depth is $1.4-1.6 \mathrm{~m}$, the height of bamboo pile above the water is $1.5 \mathrm{~m}$, and the bamboo piles are driving into the ground in swamp area in length about $2.5 \mathrm{~m}$. The thickness of bamboo stick in horizontal direction is about $10 \mathrm{~mm}$, the width of each bamboo stick is $40-60 \mathrm{~mm}$, the vertical space of bamboo stick is $600 \mathrm{~mm}$, and the dimension of the bamboo structures is listed in Table 2.

Table 2. Bamboo structural dimension

\begin{tabular}{|c|c|c|c|c|c|c|}
\hline \multirow{2}{*}{$\begin{array}{c}\text { Bamboo pile space } \\
(\mathrm{mm})\end{array}$} & \multicolumn{2}{|c|}{ Bamboo diameter $(\mathrm{mm})$} & \multirow{2}{*}{$\begin{array}{l}\text { Thickness of } \\
\text { bamboo pile } \\
\text { (mm) }\end{array}$} & \multicolumn{3}{|c|}{ Connection member (mm) } \\
\hline & Outside & Inside & & $\begin{array}{l}\text { Distance to top of the } \\
\text { bamboo pile }\end{array}$ & Diameter & Thickness \\
\hline 290 & 89 & 46 & 22 & 200 & 60 & 15 \\
\hline
\end{tabular}

Note: The dimension above is average dimension.

3.2 Physical and mechanical parameter of bamboo

The bamboo material used should be in a dry condition. The physical and mechanical properties of local bamboo material are listed in Table 3.

Table 3. Physical and mechanical properties for bamboo material

\begin{tabular}{c|c|c|c|c|c|c|c|c|c}
\hline \multirow{2}{*}{ Density } & $\begin{array}{c}\text { Tensile } \\
\text { strength }\end{array}$ & $\begin{array}{c}\text { Compressive } \\
\text { strength }\end{array}$ & $\begin{array}{c}\text { Shear } \\
\text { strength }\end{array}$ & $\begin{array}{c}\text { Flexural } \\
\text { strength }\end{array}$ & $\begin{array}{c}\text { Allowable } \\
\text { tensile } \\
\text { strength } \\
\left(\mathrm{kN} / \mathrm{m}^{3}\right)\end{array}$ & $\begin{array}{c}\text { Allowable } \\
\text { compressive } \\
\text { strength } \\
(\mathrm{MPa})\end{array}$ & $\begin{array}{c}\text { Allowable } \\
\text { shear } \\
\text { strength } \\
(\mathrm{MPa})\end{array}$ & $\begin{array}{c}\text { Elastic } \\
\text { modulus }\end{array}$ & $\begin{array}{c}\text { Flexural } \\
\text { modulus }\end{array}$ \\
\hline 7.32 & 124 & 55.1 & 66 & 116 & 27.6 & 27.6 & 14.8 & 12 & 70 \\
\hline
\end{tabular}

3.3 Total moment of inertia of bamboo structure

The average thickness of bamboo structures including bamboo stick, bamboo crossbeam and bamboo pile is $159 \mathrm{~mm}$. The total moment of inertia can be calculated as Table 4 .

Table 4. Total moment of inertial of bamboo structures

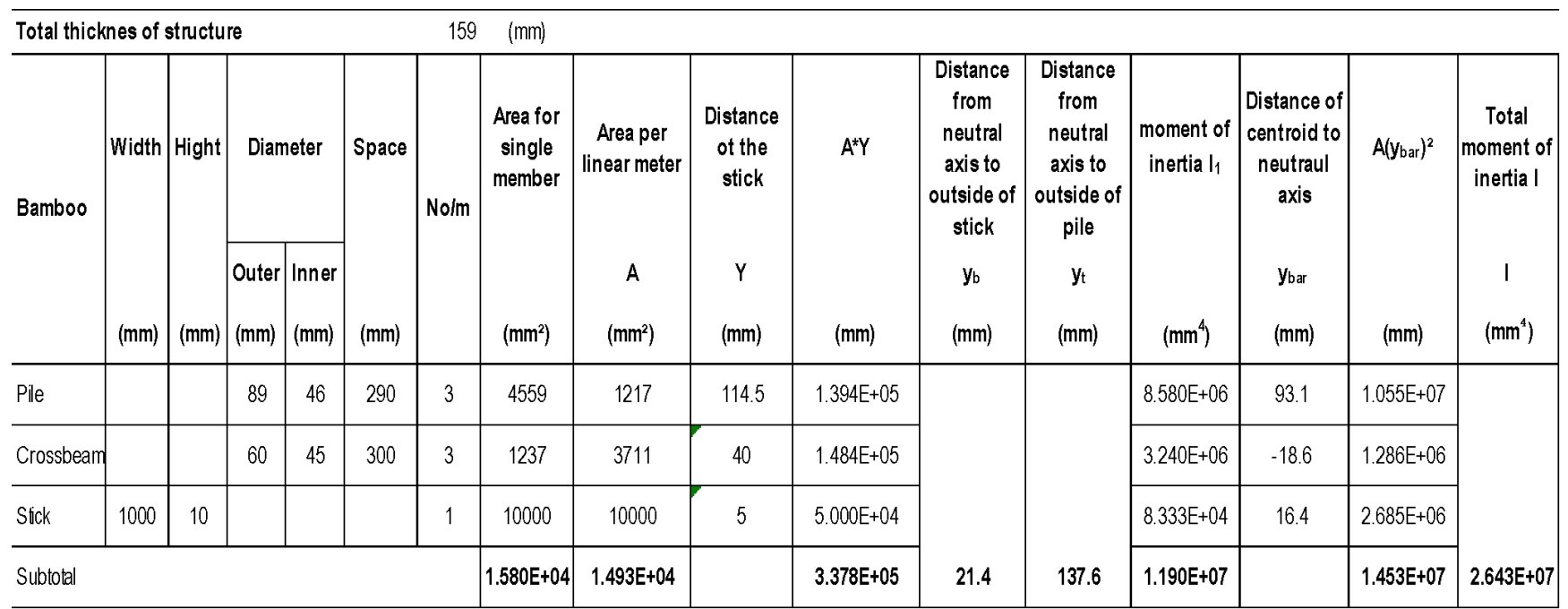

4. Structural Calculation for Bamboo Structure

4.1 Structural analysis of bamboo stick 
The lateral load will reach maximum when the sand fill material is on top of the bamboo piles. The space of crossbeam is $500 \mathrm{~mm}$ as shown in Figure 2, the lateral loading values on bamboo pile is shown in Figure 3, the moment and shear diagram for bamboo pile is shown in Figure 4 and 5 respectively. At the location of the reinforcement, the horizontal displacement is designed as zero. Figure 4 shows that the maximum moment is located at bottom of the bamboo pile with value $0.49 \mathrm{kN}-\mathrm{m} / \mathrm{m}$. Figure 5 shows that the maximum shear force is $5.62 \mathrm{kN} / \mathrm{m}$ acting on last crossbeam.

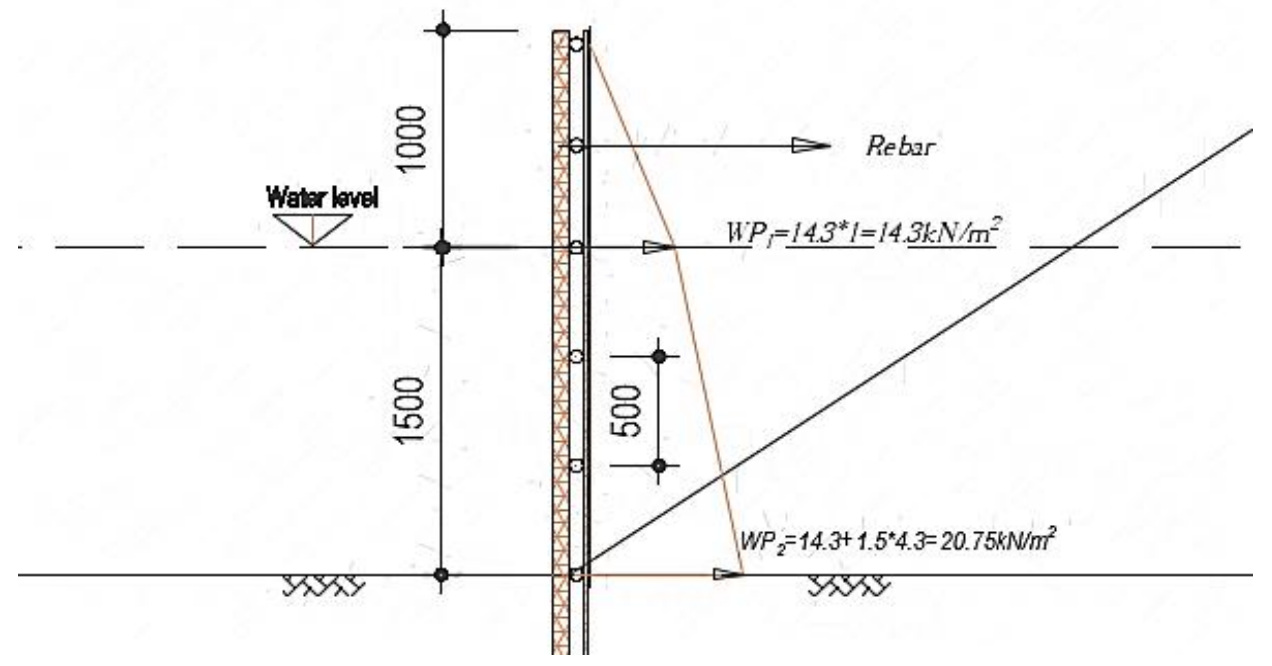

Figure 2. Forces for bamboo stick

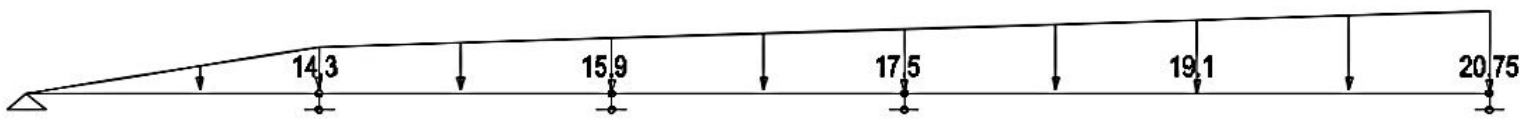

Figure 3. Lateral forces on bamboo stick (turned $90^{\circ}$ )

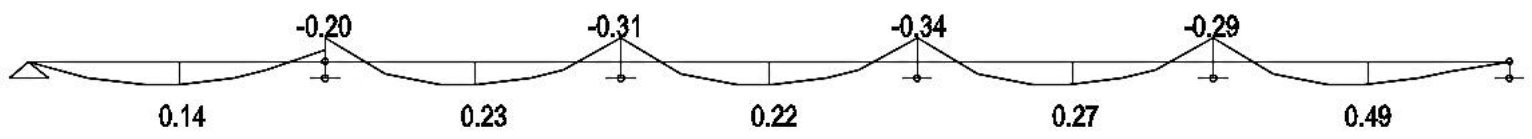

Figure 4. Moments for bamboo stick

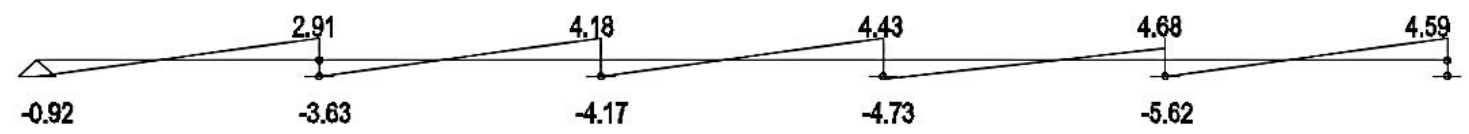

Figure5. Shear diagram for bamboo stick

Table 5. Tensile stress of crossbeam under different thickness

\begin{tabular}{c|c|c|c|c|c|c|c}
\hline Maximum moment & $(\mathrm{kN}-\mathrm{m} / \mathrm{m})$ & 0.49 & 0.49 & 0.49 & 0.49 & 0.49 & 0.49 \\
\hline $\begin{array}{c}\text { Thickness of bamboo } \\
\text { stick, } \mathrm{H}\end{array}$ & $(\mathrm{mm})$ & 10 & 11 & 12 & 13 & 14 & 15 \\
\hline Flexural modulus, Wn & $\left(\mathrm{m}^{2}\right)$ & $1.6667 \mathrm{E}-05$ & $2.0167 \mathrm{E}-05$ & 0.000024 & $2.8167 \mathrm{E}-05$ & $3.2667 \mathrm{E}-05$ & 0.0000375 \\
\hline Tensile stress, $\sigma$ & $(\mathrm{MPa})$ & 29.4 & 24.3 & 20.42 & 17.4 & 15 & 13.07 \\
\hline
\end{tabular}

The flexural modulus of bamboo stick is $\mathrm{Wn}=\mathrm{bh} 2 / 6$, The tensile stress is $\sigma=\mathrm{M} / \mathrm{Wn}$, thus, the tensile stress under different thickness of bamboo stick with space of $50 \mathrm{~mm}$ can be calculated. When tensile stress is larger than the bamboo 
material allowable strength of $27.6 \mathrm{MPa}$, that is, the thickness of the material does not meet the requirements, a thicker bamboo material should be selected. When the thickness of the bamboo stick is fixed, the space of the crossbeam can be adjusted and new calculation could be done, in order to make the tensile stress in crossbeam is less than the allowable stress of the bamboo. For the case of this design, the thickness of $11 \mathrm{~mm}$ and above can meet the design requirements.

4.2 Structural analysis of bamboo pile

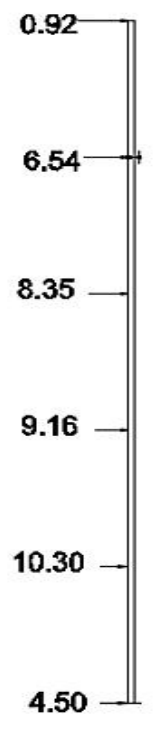

Loading diagram

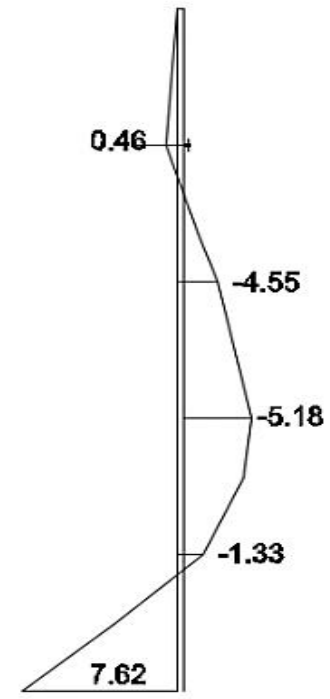

Moment diagram

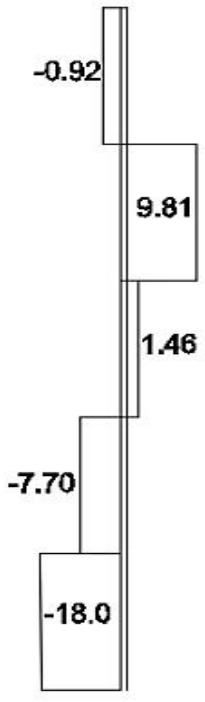

Shear diagram

Figure 6. Loading, moment and shear diagram for the bamboo pile

The forces acting on bamboo crossbeam is calculated, the same reaction force will act on the bamboo pile. The results of the bamboo pile are shown in Figure 6. The end section of bamboo pile that is the point contact with the ground has maximum bending moment of $7.67 \mathrm{kN}-\mathrm{m}$ and has the maximum Shear force of $18 \mathrm{kN} / \mathrm{m}$. The value can be reduced when the less space of bamboo pile is applied.

4.3 Determining space of the bamboo pile

Table 6. Design results for bamboo piling space

\begin{tabular}{|c|c|c|c|c|c|c|c|}
\hline Moment, $\mathrm{H}$ & $(\mathrm{kN}-\mathrm{m})$ & 7.67 & 7.67 & 7.67 & 7.67 & 7.67 & 7.67 \\
\hline Shear force, $S$ & $(\mathrm{kN})$ & 18 & 18 & 18 & 18 & 18 & 18 \\
\hline Number of pile, $\mathrm{N}$ & $(\mathrm{No} / \mathrm{m})$ & 1 & 2 & 3 & 4 & 5 & 6 \\
\hline Bamboo pile space & $(\mathrm{mm})$ & 1000 & 500 & 333 & 250 & 200 & 167 \\
\hline $\begin{array}{c}\text { Moment on single } \\
\text { pile, N }\end{array}$ & $(\mathrm{kN}-\mathrm{m})$ & 7.7 & 3.8 & 2.6 & 1.9 & 1.5 & 1.3 \\
\hline $\begin{array}{l}\text { Flexual modulus } \\
\text { on single pile, Wn }\end{array}$ & $\left(\mathrm{m}^{2}\right)$ & $6.04158 \mathrm{E}-05$ & $6.04158 \mathrm{E}-05$ & $6.04158 \mathrm{E}-05$ & $6.04158 \mathrm{E}-05$ & $6.04158 \mathrm{E}-05$ & $6.04158 \mathrm{E}-05$ \\
\hline $\begin{array}{c}\text { Tensile stress on } \\
\text { sigle pile, } \sigma \mathrm{t}\end{array}$ & $(\mathrm{MPa})$ & 127.0 & 63.5 & 42.3 & 31.7 & 25.4 & 21.2 \\
\hline $\begin{array}{c}\text { Shear force on } \\
\text { single pile,S1 }\end{array}$ & $(\mathrm{kN})$ & 18 & 9 & 6 & 4.5 & 3.6 & 3 \\
\hline $\begin{array}{c}\text { Shear stress on } \\
\text { single pile, } \sigma \mathrm{s}\end{array}$ & $(\mathrm{MPa})$ & 39.05 & 19.53 & 13.02 & 9.76 & 7.81 & 6.51 \\
\hline
\end{tabular}

According to section above, when the number of the bamboo pile is increased, the tensile stress on single pile can be calculated, the reasonable space of the bamboo pile can be determined as shown in Table 6 above. It shows that according to shear force control criteria, reasonable number of the bamboo pile is 3 in one linear meter, the space is $330 \mathrm{~mm}$, thus, 
the shear stress of single bamboo pile is $13.02 \mathrm{MPa}$, which is less than the allowable shear strength of $14.6 \mathrm{MPa}$. According to the tensile stress control criteria, the 5 No. of the pile with $200 \mathrm{~mm}$ space of the bamboo pile is selected, and the maximum tensile stress is $25.4 \mathrm{MPa}$, which is less than the allowable tensile stress of $27.6 \mathrm{MPa}$. The more stringent criteria should be applied for work safety.

4.4 Space and diameter of tensile reinforcement

The lateral pressure of special fine sand and water act on bamboo pile is listed in Table 7.

Table 7. Lateral pressure of special fine sand and water on bamboo pile

\begin{tabular}{|c|c|c|c|c|c|c|c|c|}
\hline \multicolumn{3}{|c|}{ Bamboo pile length (m) } & \multirow{2}{*}{$\begin{array}{l}\text { Special fine sand } \\
\text { Density }\left(\mathrm{kN} / \mathrm{m}^{3}\right)\end{array}$} & \multicolumn{2}{|c|}{ Horizontal pressure $(\mathrm{kN} / \mathrm{m} 2)$} & \multicolumn{3}{|c|}{ Horizontal load $(\mathrm{kN} / \mathrm{m})$} \\
\hline $\begin{array}{l}\text { Water } \\
\text { above }\end{array}$ & $\begin{array}{l}\text { Under } \\
\text { water }\end{array}$ & Ground & & Water above & Under water & $\begin{array}{l}\text { Water } \\
\text { above }\end{array}$ & $\begin{array}{l}\text { Under } \\
\text { water }\end{array}$ & Total sum \\
\hline 1 & 1.5 & 3 & 14.3 & 14.30 & 20.75 & 7.15 & 26.29 & 33.44 \\
\hline
\end{tabular}

According to Table 7, the lateral loading to be taken by reinforcement is calculated and the result is listed in Table 8 .

Table 8 shows that when $6 \mathrm{~mm}$ diameter reinforcement used, the $11.6 \mathrm{~m}$ space of the reinforcement can be arranged. However, for the safety and minimize the displacement of the bamboo pile, half of the space should be used.

Table 8. Horizontal pressure to be taken by reinforcement

\begin{tabular}{c|c|c|c|c|c|c}
\hline Diameter & Area & $\begin{array}{c}\text { Yielding } \\
\text { strength } \\
(\mathrm{mm})\end{array}$ & $\begin{array}{c}\text { Allowable tensile } \\
\text { strength } \\
\left(\mathrm{mm}^{2}\right)\end{array}$ & $\begin{array}{c}\text { Allowable } \\
\text { tensile force } \\
(\mathrm{MPN})\end{array}$ & $\begin{array}{c}\text { Total horizontal } \\
\text { load } \\
(\mathrm{kN} / \mathrm{m})\end{array}$ & $\begin{array}{c}\text { Design } \\
\text { space } \\
(\mathrm{m})\end{array}$ \\
\hline 6 & 28.3 & 275.0 & 138 & 389 & 33.4 & 11.6 \\
\hline 8 & 50.3 & 275.0 & 138 & 691 & 33.4 & 20.7 \\
\hline
\end{tabular}

\section{FEA Analysis}

\subsection{Maximum consolidation settlement}

FEA is used to analyze whole section of the road, the result shows that the maximum vertical settlement is $69.4 \mathrm{~mm}$ and it occurs at middle section, the total consolidation time for the cohesive soil is 330 days at upper section and it is 343 days for lower section of the road.

5.2 Maximum average effective stress of subgrade

When bamboo pile construction completed, the maximum average effective stress of subgrade is $72 \mathrm{kPa}$, the maximum effective stress is $121.5 \mathrm{kPa}$ and total stress is $235 \mathrm{kPa}$. The result shows that the length of pile under the ground is important. It limits the displacement of the side slope to the deep ground and prevents the heaving of the bottom of the slope.

5.3 Maximum settlement on top of the road

According to the FEA analysis, the maximum settlement on top of the road near the shoulder is $11.3 \mathrm{~mm}$ when construction of sub-base is completed.

\section{Construction Method, Procedure and Quality Control}

6.1 Construction method and procedure

A movable bamboo piling platform should be prepared as shown in Figure 7. Besides, bamboo materials for bamboo piles, crossbeams and bamboo sticks should be prepared. The flex material, the reinforcement in $6 \mathrm{~m}$ space as shown in Figure 8 should be provided for the bamboo structure. 


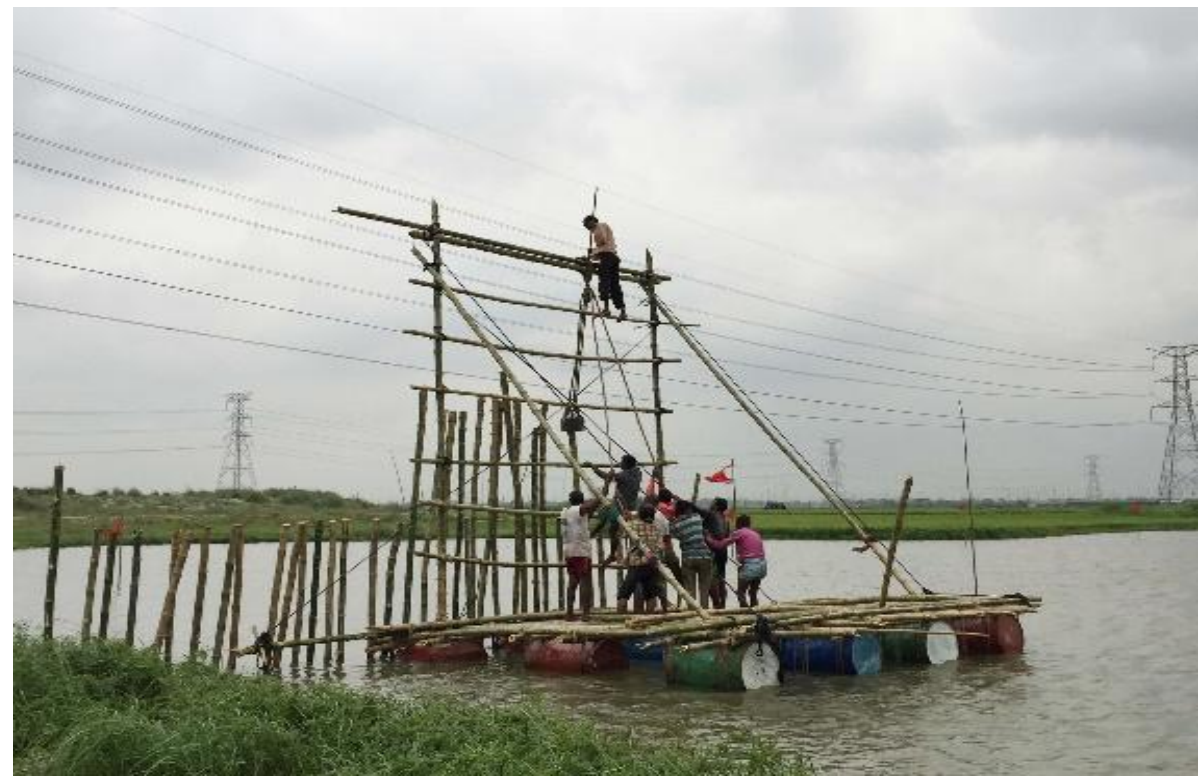

Figure 7. Bamboo piling

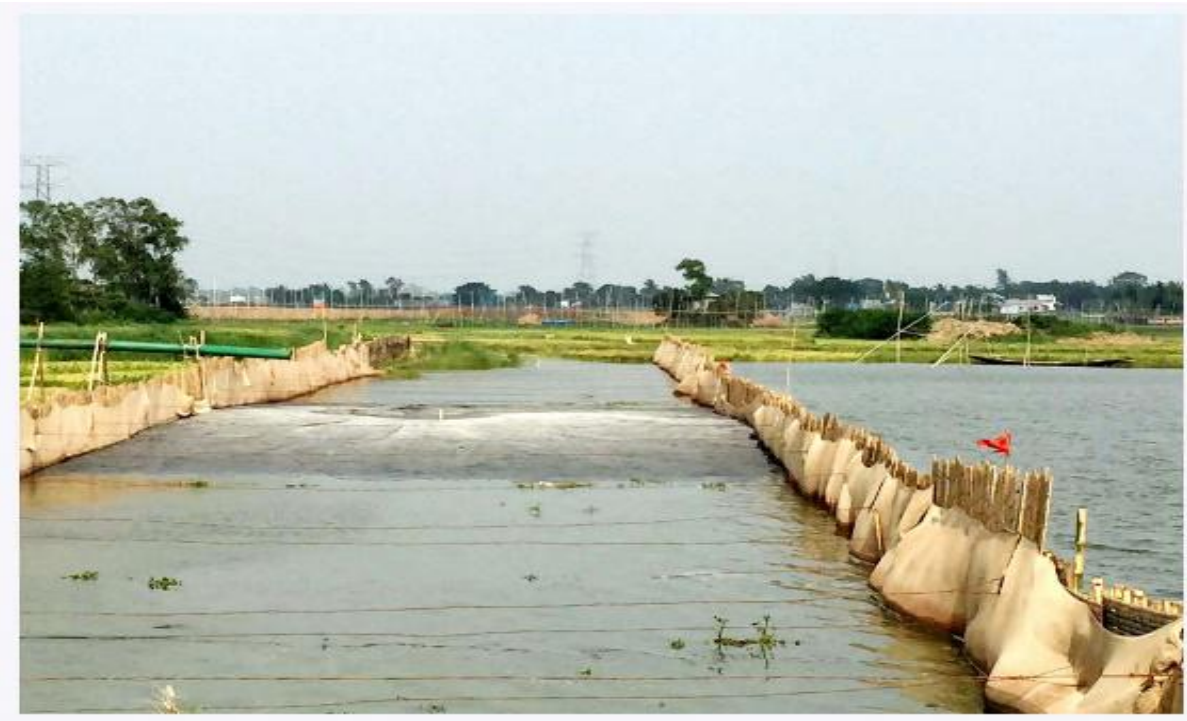

Figure 8. Bamboo structure and sand fill

Preloading should be applied to the reinforcement to keep the horizontal displacement zero under the maximum lateral pressure. The works above can be completed by 10-12 workers.

After works above are completed, sand fill material can be applied in the middle of the bamboo structures. The sand fill material should be applied layer by layer; the thickness of layer can be $1-2 \mathrm{~m}$, depending on the total height of the embankment. The excavator should be applied to trim the side slope, and the plastic material should be applied to the inner side of slope when trimming side slope of the road. After cofferdam being done, another layer of the sand fill should be start. Same procedures can be applied to the next layer until close to the bottom level of the sub-base. Considering settlement of the sand fill, more than $0.3-0.5 \mathrm{~m}$ thickness of sand fill should be applied.

The working procedure of road construction using specially found sand is shown in Figure 9. 


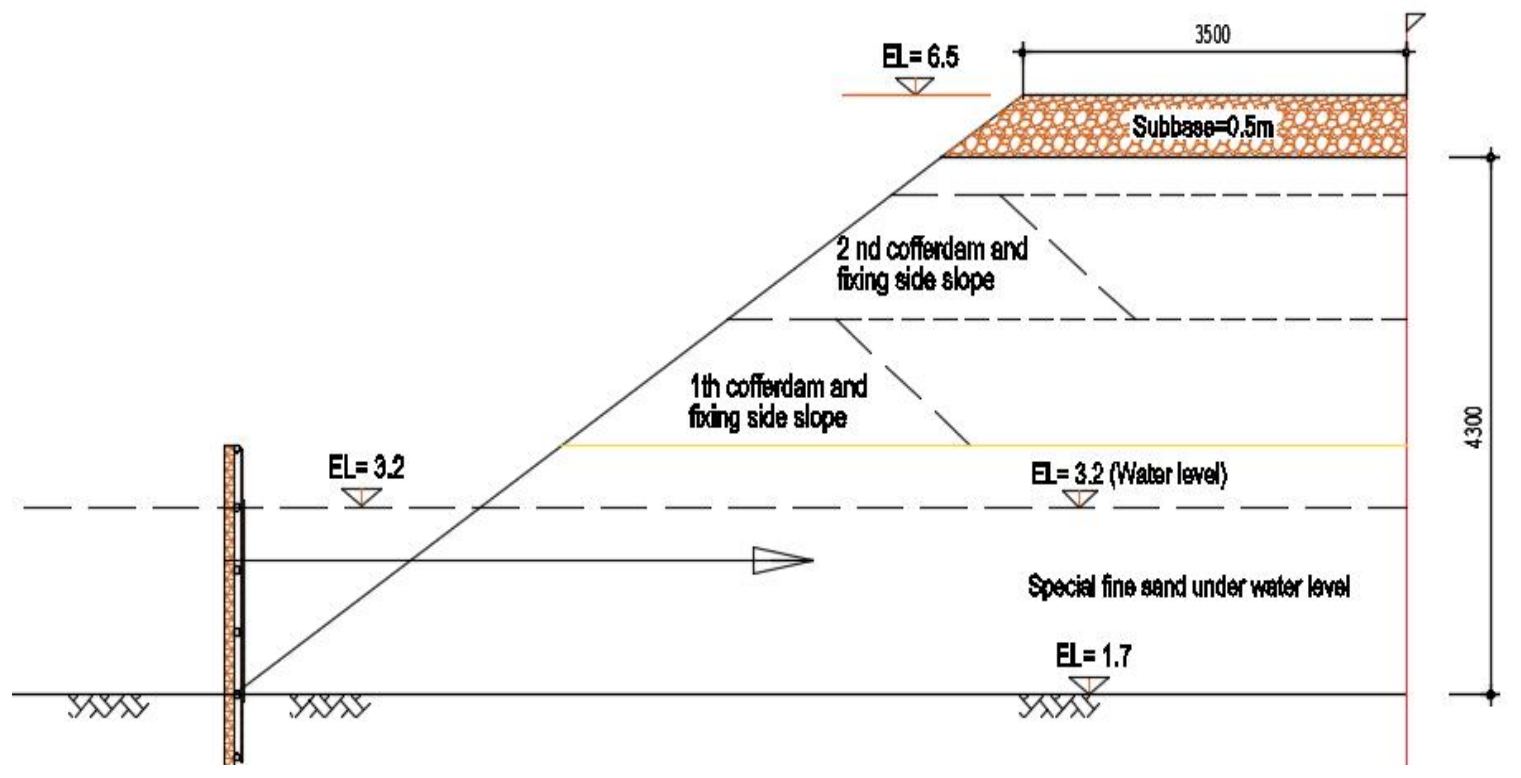

Figure 9. Procedure for sand fill of the road work

Rolling should be applied when sand fill is completed and there is no much water inside the special fines sand material. Sand filling and trimming of the side slope by excavator are one of the most important processes for compaction. The settlement of both inside the existing ground and in subgrade layer will occur simultaneously when carrying out of the sand fill work. After subgrade layer completed by using the special fine sand, the sub-base material made of brick chips and other available suitable materials should be provided and compacted in time.

\subsection{Construction quality control}

Bamboo material that should be used over 4 years and in dry condition. The bamboo piles should be provided according to the design space. The depth of the bamboo pile should be driven to the required depth. The thickness of the bamboo stick used should be larger than the design value. The flex material should be strong to minimize damage during the sand fill work. When fine sand is lost, strength will be lost. Therefore, the sub-base material has to be applied to the sand filling material in time for road traffic. For high embankment, cofferdam should be provided for every $1-2 \mathrm{~m}$ sand filling, and "Z" or "U" shaped excavation should be made in order to fill sand in the middle of the road. Plant with good root and strong life such as reed or suitable grass available locally should be provided in order to minimize erosion of side slopes by rain. The chute with sandbags should be provided every $10-20 \mathrm{~m}$ so that water from road surface can be drained at the designed position. The bamboo structures should be designed properly, and two crossbeams can be provided at location of the reinforcement, so that the load can be distributed uniformly on bamboo piles. Compaction of the road subgrade is an important process to ensure that the road constructed is strong enough. The preloading should be applied to the reinforcement so that the horizontal displacement will be close to zero under the maximum lateral pressure.

The minimum side slope for sand fill is $45^{\circ}$.

\subsection{Basic safety control}

Safety facilities should be ready when working on the platform for the bamboo piling, and the boat for piling should be checked before staring the piling work. The piling workers should be selected carefully to make sure the boat can remain stable during the piling of bamboo work. Emergency plan should be prepared before the start of water work.

When trimming the side slope and working on the first cofferdam, special care should be taken to make sure the safety of the excavator. The basic settlement and proper water content should be determined before rolling the sand fill material. When hauling of the sub-base material on the subgrade made of the special find sand, pay attention to safety 
during transportation.

\section{Conclusions}

(1) Special fine sand with fine modulus of 0.42-0.62 taken from river can be used for road construction in low-lying and swamp area by providing bamboo piling and supporting system, and it is suitable for areas with scarce construction materials in countries such as Bangladesh.

(2) Special fine sand taken from the river can only be used for filling and subgrade, the quality of sub-base material has to be provided and compacted properly on the layer of the subgrade.

(3) The final consolidation settlement may take about one year, depending on the type of the materials used and types of the materials under the existing ground.

(4) The proposed structural analysis, construction method, procedures, quality control as well as safety control can be used as guidance for other project under similar conditions.

(5) The proposed method is economical and quick for road construction, and it has been successfully used in the low-lying and swamp areas.

\section{Conflicts of Interest}

The author declares no conflicts of interest regarding the publication of this paper.

\section{References}

[1] Bangladesh National Building Code (2015). Housing and Building Research Institute. 2(3): 6.

[2] Standard Tender Documents Volume 3 of 4 Technical Specifications (2001). Government of the Peoples' Republic of Bangladesh, Ministry of Communications, Roads and Highway Department. 5.

[3] Wu Z., Ju Q.F. and Zhang C.B. (2020). Study and Application of Construction Technology for Dredging -Reclamation of Large-scale Low-lying Swamp Area. Water Resources and Hydropower Engineering, 51 (S1): 80-84. 